\title{
A comparison of the radiosensitisation ability of 22 different element metal oxide nanoparticles using clinical megavoltage $\mathrm{X}$-rays
}

\author{
Alexandra Guerreiro ${ }^{1,2}$, Nicholas Chatterton ${ }^{2}$, Eleanor M. Crabb² and Jon P. Golding ${ }^{2^{*}}$ (D)
}

\author{
${ }^{*}$ Correspondence: \\ Jon.golding@open.ac.uk \\ ${ }^{2}$ School of Life, Health \\ and Chemical Sciences, The \\ Open University, Milton \\ Keynes, UK \\ Full list of author information \\ is available at the end of the \\ article
}

\begin{abstract}
Background: A wide range of nanoparticles (NPs), composed of different elements and their compounds, are being developed by several groups as possible radiosensitisers, with some already in clinical trials. However, no systematic experimental survey of the clinical X-ray radiosensitising potential of different element nanoparticles has been made. Here, we directly compare the irradiation-induced (10 Gy of 6-MV X-ray photon) production of hydroxyl radicals, superoxide anion radicals and singlet oxygen in aqueous solutions of the following metal oxide nanoparticles: $\mathrm{Al}_{2} \mathrm{O}_{3}, \mathrm{SiO}_{2}, \mathrm{Sc}_{2} \mathrm{O}_{3}, \mathrm{TiO}_{2}, \mathrm{~V}_{2} \mathrm{O}_{5}$, $\mathrm{Cr}_{2} \mathrm{O}_{3}, \mathrm{MnO}_{2}, \mathrm{Fe}_{3} \mathrm{O}_{4}, \mathrm{CoO}, \mathrm{NiO}, \mathrm{CuO}, \mathrm{ZnO}, \mathrm{ZrO}_{2}, \mathrm{MoO}_{3}, \mathrm{Nd}_{2} \mathrm{O}_{3}, \mathrm{Sm}_{2} \mathrm{O}_{3}, \mathrm{Eu}_{2} \mathrm{O}_{3}, \mathrm{Gd}_{2} \mathrm{O}_{3}$, $\mathrm{Tb}_{4} \mathrm{O}_{7}, \mathrm{Dy}_{2} \mathrm{O}_{3}, \mathrm{Er}_{2} \mathrm{O}_{3}$ and $\mathrm{HfO}_{2}$. We also examine DNA damage due to these NPs in unirradiated and irradiated conditions.
\end{abstract}

Results: Without any X-rays, several NPs produced more radicals than water alone. Thus, $\mathrm{V}_{2} \mathrm{O}_{5} \mathrm{NPs}$ produced around 5-times more hydroxyl radicals and superoxide radicals. $\mathrm{MnO}_{2} \mathrm{NPs}$ produced around 10-times more superoxide anions and $\mathrm{Tb}_{4} \mathrm{O}_{7}$ produced around 3-times more singlet oxygen. Lanthanides produce fewer hydroxyl radicals than water. Following irradiation, $\mathrm{V}_{2} \mathrm{O}_{5} \mathrm{NPs}$ produced nearly 10 -times more hydroxyl radicals than water. Changes in radical concentrations were determined by subtracting unirradiated values from irradiated values. These were then compared with irradiation-induced changes in water only. Irradiation-specific increases in hydroxyl radical were seen with most NPs, but these were only significantly above the values of water for $\mathrm{V}_{2} \mathrm{O}_{5}$, while the Lanthanides showed irradiation-specific decreases in hydroxyl radical, compared to water. Only $\mathrm{TiO}_{2}$ showed a trend of irradiation-specific increase in superoxides, while $\mathrm{V}_{2} \mathrm{O}_{5}, \mathrm{MnO}_{2}, \mathrm{CoO}, \mathrm{CuO}, \mathrm{MoO}_{3}$ and $\mathrm{Tb}_{4} \mathrm{O}_{7}$ all demonstrated significant irradiation-specific decreases in superoxide, compared to water. No irradiation-specific increases in singlet oxygen were seen, but $\mathrm{V}_{2} \mathrm{O}_{5}, \mathrm{NiO}, \mathrm{CuO}, \mathrm{MoO}_{3}$ and the lanthanides demonstrated irradiation-specific decreases in singlet oxygen, compared to water. $\mathrm{MoO}_{3}$ and $\mathrm{CuO}$ produced DNA damage in the absence of radiation, while the highest irradiation-specific DNA damage was observed with $\mathrm{CuO}$. In contrast, $\mathrm{MnO}_{2}, \mathrm{Fe}_{3} \mathrm{O}_{4}$ and CoO were slightly protective against irradiation-induced DNA damage.

Conclusions: Beyond identifying promising metal oxide NP radiosensitisers and radioprotectors, our broad comparisons reveal unexpected differences that suggest the surface chemistry of NP radiosensitisers is an important criterion for their success. 
Keywords: Radiosensitiser, X-ray, Megavoltage, Metal oxide, Nanoparticle, Survey, Radicals, DNA damage

\section{Background}

Water radiolysis by ionising radiation results in the formation of several species, mainly: $\mathrm{e}^{-}$aq, $\mathrm{OH},{ }^{\prime} \mathrm{H}, \mathrm{H}_{3} \mathrm{O}^{+}, \mathrm{OH}^{-}, \mathrm{O}_{2} \mathrm{H}, \mathrm{H}_{2} \mathrm{O}_{2}$ and $\mathrm{H}_{2}$. These products react with one another to form secondary species such as $\mathrm{O}_{2}, \mathrm{O}_{2}{ }^{-}$and ${ }^{\circ} \mathrm{O}_{3}$, with many additional short-lived intermediates (reviewed in Le Caër 2011). Water radiolysis products range from highly oxidising (e.g. ' $\mathrm{OH}, \mathrm{H}_{2} \mathrm{O}_{2}$ and $\mathrm{O}_{2}$ ) to highly reducing (e.g. ' $\mathrm{H},{ }^{\prime} \mathrm{e}_{\mathrm{aq}}^{-}$and ${ }^{\prime} \mathrm{O}_{2}{ }^{-}$). These reactive species damage biological molecules and contribute around $60 \%$ of the biological damage due to X-ray radiotherapy (Saenko et al. 2013; Zhang et al. 2016; Jayakumar et al. 2014; reviewed in Baskar et al. 2014). Although each clinical X-ray irradiation session only lasts for a few minutes, the radical-mediated damage can induce prolonged metabolic oxidative stress that continues to damage cells long after irradiation (Azzam et al. 2012).

Theoretical studies (McMahon et al. 2016; Hwang et al. 2017; Haume et al. 2016; Roeske et al. 2007) and experimental studies (Retif et al. 2015; Liu et al. 2018) have demonstrated that X-ray-induced radical formation can be greatly increased in the vicinity of nanoparticles of high atomic number $(Z)$ elements, their oxides or sulphides [e.g. Ag: Liu et al. (2016); Gd: Luchette et al. (2014), Lux et al. (2018); Hf: Marill et al. (2014); Pt: Muhammad et al. (2018); Au: Haume et al. (2016), Rahman et al. (2014); Bi: Algethami (2015), Sahu and Cates (2017)], which have large X-ray absorption cross sections and produce a shower of secondary electrons when irradiated. For this reason, high atomic number nanoparticles have been the focus of nanoparticle radiosensitiser research, some of which are being clinically evaluated (Liu et al. 2018), such as the Gd NP, AGuIX (Lux et al. 2018) and the Hf NP, NBTXR3 (Marill et al. 2014), both of which are currently in Phase II clinical trials (NCT03818386 and NCT03589339).

However, NPs of many lower atomic number element oxides have been shown to be effective radiosensitisers, such as: $\mathrm{Al}$ (Roth et al. 2011), Si (David Gara et al. 2012; Generalov et al. 2015; Zhao et al. 2016), Ca (Chu et al. 2013), Ti (Morrison et al. 2017), Fe (Khoei et al. 2014), Cu (Jiang et al. 2019), Zn (Generalov et al. 2015), Zr (Carrasco-Flores and LaVerne 2007). This suggests that other, physico-chemical and chemical processes, likely involving the nanoparticle surface, contribute to the overall pool of X-ray-induced radicals.

What is missing, however, are systematic experimental comparisons of these different element NPs as radiosensitisers. Most in vitro studies have been limited to comparing small ranges of elements, or more often to different compounds or surface functionalisation of a single element NP. Experimental differences, such as X-ray energy and dose, and concentration of nanoparticles further impede comparisons (Hwang et al. 2017; Rahman et al. 2014; Retif et al. 2015). Recent proposals have been made to standardise these parameters (Retif et al. 2015; Schuemann et al. 2019), but it will take time for these to become routinely adopted.

Only two studies have been published using a broad range of NPs, both with gamma radiation. Petrik et al. (2001) compared hydrogen production from adsorbed water on a wide range of 28 different element metal oxide powders (Petrik et al. 2001). Chelnokov 
Table 1 NP diameters measured by TEM and DLS

\begin{tabular}{|c|c|c|c|c|c|}
\hline NP & $\begin{array}{l}\text { TEM } \\
\text { Mean dia (nm) } \\
\pm S D\end{array}$ & $\begin{array}{l}\text { TEM } \\
\text { Mode dia } \\
(\mathrm{nm})\end{array}$ & $\begin{array}{l}\text { DLS } \\
\text { Median dia (nm) } \\
\pm \text { SD }\end{array}$ & $\begin{array}{l}\text { DLS } \\
\text { Poly-dispersity }\end{array}$ & $\begin{array}{l}\text { Supplier } \\
\text { quoted TEM } \\
\text { dia }(n m)\end{array}$ \\
\hline $\mathrm{Al}_{2} \mathrm{O}_{3}$ & $49 \pm 38$ & 14 & $781 \pm 432$ & 0.21 & $<50$ \\
\hline $\mathrm{SiO}_{2}$ & $46 \pm 45$ & 13 & $424 \pm 364$ & 0.25 & $10-20$ \\
\hline $\mathrm{Sc}_{2} \mathrm{O}_{3}$ & $50 \pm 34$ & 13 & $430 \pm 78$ & 0.04 & $<80$ \\
\hline $\mathrm{TiO}_{2}$ & $61 \pm 43$ & 14 & $439 \pm 315$ & 0.17 & 21 \\
\hline $\mathrm{V}_{2} \mathrm{O}_{5}$ & $47 \pm 36$ & 13 & $717 \pm 401$ & 0.39 & $<80$ \\
\hline $\mathrm{Cr}_{2} \mathrm{O}_{3}$ & $56 \pm 51$ & 13 & $99 \pm 55$ & 0.16 & 60 \\
\hline $\mathrm{MnO}_{2}$ & $64 \pm 55$ & 14 & $25 \pm 6$ & 0.57 & 50 \\
\hline $\mathrm{Fe}_{3} \mathrm{O}_{4}$ & $49 \pm 40$ & 15 & $805 \pm 336$ & 0.14 & 50-100 \\
\hline $\mathrm{CoO}$ & $46 \pm 39$ & 14 & $71 \pm 15$ & 0.47 & 50 \\
\hline $\mathrm{NiO}$ & $58 \pm 44$ & 19 & $375 \pm 283$ & 0.23 & $<50$ \\
\hline $\mathrm{CuO}$ & $40 \pm 29$ & 16 & $132 \pm 59$ & 0.23 & $<50$ \\
\hline $\mathrm{ZnO}$ & $44 \pm 30$ & 13 & $353 \pm 238$ & 0.27 & $<100$ \\
\hline $\mathrm{ZrO}_{2}$ & $50 \pm 32$ & 26 & $155 \pm 31$ & 0.59 & 40 \\
\hline $\mathrm{MoO}_{3}$ & $30 \pm 21$ & 13 & $203 \pm 47$ & 0.06 & $13-80$ \\
\hline $\mathrm{Nd}_{2} \mathrm{O}_{3}$ & $64 \pm 51$ & 15 & $227 \pm 131$ & 0.53 & $30-45$ \\
\hline $\mathrm{Sm}_{2} \mathrm{O}_{3}$ & $40 \pm 44$ & 13 & $41 \pm 31$ & 0.69 & $15-45$ \\
\hline $\mathrm{Eu}_{2} \mathrm{O}_{3}$ & $69 \pm 56$ & 13 & $8 \pm 2$ & 0.54 & $10-100$ \\
\hline $\mathrm{Gd}_{2} \mathrm{O}_{3}$ & $26 \pm 37$ & 13 & $67 \pm 24$ & 1.00 & $10-100$ \\
\hline $\mathrm{Tb}_{4} \mathrm{O}_{7}$ & $107 \pm 108$ & 13 & $1073 \pm 340$ & 0.10 & $10-100$ \\
\hline $\mathrm{Dy}_{2} \mathrm{O}_{3}$ & $42 \pm 30$ & 14 & $938 \pm 301$ & 0.18 & 30 \\
\hline $\mathrm{Er}_{2} \mathrm{O}_{3}$ & $64 \pm 67$ & 13 & $333 \pm 41$ & 0.01 & $10-100$ \\
\hline $\mathrm{HfO}_{2}$ & $105 \pm 84$ & 18 & $74 \pm 13$ & 0.69 & $61-80$ \\
\hline
\end{tabular}

Integer values \pm SD

et al. (2014) compared solvated electron production from six different element NPs (Chelnokov et al. 2014).

Because of the difficulties in comparing radiosensitisers across studies, we have performed a survey of a broad range of 22 different metal oxide NPs, to examine their intrinsic ability to generate reactive oxygen species and damage plasmid DNA under control and irradiated conditions using clinically relevant megavoltage X-ray photons (10 Gy of 6-MV X-rays).

Metal oxides, rather than pure metals, were chosen because nearly all of the transition metal elements we use are unstable in water and react to become oxides. We find that some metal oxides increased radiation-induced radical formation $\left(\mathrm{V}_{2} \mathrm{O}_{5}\right.$, for hydroxyl radicals; $\mathrm{TiO}_{2}$ for superoxides) while others were radioprotective. For instance, the lanthanide oxides produced far fewer hydroxyl radicals than irradiated water only. Irradiation-induced DNA damage was greatest with $\mathrm{CuO}$ NPs.

\section{Results}

\section{NP characterisation}

Transmission electron microscopy (TEM) and dynamic light scattering (DLS) were used to measure, respectively, the core and hydrodynamic size distributions of the NPs (Table 1; Additional file 1: Figure S1, Additional file 2: Figure S2). By TEM, the most frequent diameter (mode) of each NP lay in a narrow range between 13 and $26 \mathrm{~nm}$. 
Hydrodynamic diameter was generally similar or larger than the corresponding TEM value, suggesting some aggregation in solution.

X-ray diffraction (XRD) confirmed the crystal phase identity of all NPs, except $\mathrm{Eu}_{2} \mathrm{O}_{3}$ and $\mathrm{Gd}_{2} \mathrm{O}_{3}$ for which there was no close match in our database (Additional file 3: Figure S3).

\section{Radical formation}

Three fluorogenic probes were used to detect different types of radical: coumarin-3-carboxylic acid (CCA) detects hydroxyl radicals, dihydroethidium (DHE) detects superoxides and singlet oxygen sensor green (SOSG) detects singlet oxygen. Tables of raw fluorescence data, fluorescence-to-molarity calibration curves and corrected molarity data for $2.5 \mathrm{mM}$ NPs with different concentrations of oxidised probes are presented in Additional file 4, while the corrected molarity data are also presented graphically in Figs. 1, 2, 3.

For the hydroxyl radical probe CCA, the graph (Fig. 1a) is dominated by $\mathrm{V}_{2} \mathrm{O}_{5}$, which shows high hydroxyl probe fluorescence, even without irradiation.

After subtracting the non-irradiated control values for each sample ('real' values, Fig. 1b), $\mathrm{V}_{2} \mathrm{O}_{5}$ still demonstrates the largest irradiation-induced increase in hydroxyl radicals. Most of the other NPs show modest irradiation-induced increases in hydroxyl radicals, similar to water. However, the lanthanides: $\mathrm{Nd}_{2} \mathrm{O}_{3}, \mathrm{Sm}_{2} \mathrm{O}_{3}, \mathrm{Eu}_{2} \mathrm{O}_{3}, \mathrm{Gd}_{2} \mathrm{O}_{3}, \mathrm{~Tb}_{4} \mathrm{O}_{7}$, $\mathrm{Dy}_{2} \mathrm{O}_{3}$ and $\mathrm{Er}_{2} \mathrm{O}_{3}$ do not show any hydroxyl radical formation even following irradiation, suggesting this group of NPs participate in reactions that destroy hydroxyl radicals or inhibit their formation, resulting in no net increase in hydroxyl radicals.

For the superoxide anion probe DHE, the highest values are for $\mathrm{MnO}_{2}$, and $\mathrm{V}_{2} \mathrm{O}_{5}$, both of which show high superoxide probe fluorescence even in the absence of irradiation (Fig. 2a).

After subtracting the non-irradiated control values for each sample (Fig. 2b), most NPs show similar irradiation-induced superoxide values to water only. One possible exception is $\mathrm{TiO}_{2}$, which appears to show a slightly higher irradiation-induced production of superoxides than water. More significantly, although $\mathrm{V}_{2} \mathrm{O}_{5}, \mathrm{MnO}_{2}, \mathrm{CoO}, \mathrm{CuO}$ and $\mathrm{Tb}_{4} \mathrm{O}_{7}$ show greater superoxide generation overall (Fig. 2a), after subtracting the non-irradiated value they show less irradiation-induced superoxide than water (Fig. 2b), suggesting that irradiation makes less difference for these NPs as they are already actively generating these radicals, or that possibly these NPs might participate in reactions that destroy superoxides or inhibit their formation. $\mathrm{MoO}_{3}$ shows considerably lower superoxide radical formation than water after irradiation, also suggesting that it inhibits superoxide formation and/or destroys already produced superoxide radicals.

For the singlet oxygen probe SOSG, the graph is dominated by $\mathrm{Tb}_{4} \mathrm{O}_{7}$, which shows high probe fluorescence in the absence and presence of irradiation (Fig. 3a). There is also suggestion that $\mathrm{MoO}_{3}$ again shows lower radical production than water with or without irradiation.

After subtracting the non-irradiated control values for each sample (Fig. 3b), nearly half of the NPs show similar irradiation-induced singlet oxygen values to water-only: $\mathrm{Al}_{2} \mathrm{O}_{3}, \mathrm{SiO}_{2}, \mathrm{Sc}_{2} \mathrm{O}_{3}, \mathrm{TiO}_{2}, \mathrm{Cr}_{2} \mathrm{O}_{3}, \mathrm{Fe}_{3} \mathrm{O}_{4}, \mathrm{CoO}, \mathrm{ZrO}_{2}$ and $\mathrm{HfO}_{2}$. The remaining NPs all show a tendency for less irradiation-induced singlet oxygen production than water; 


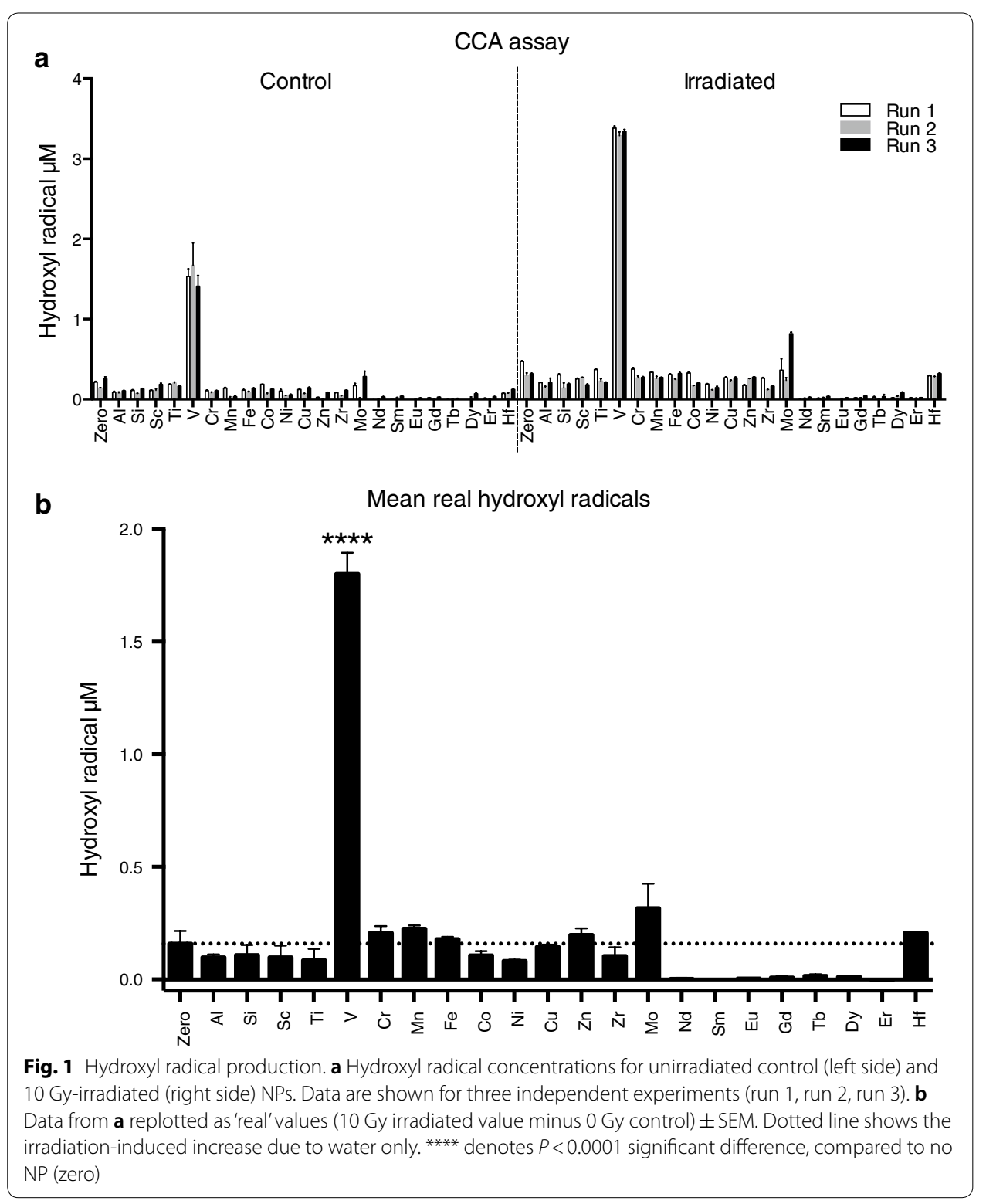

significantly lower in the cases of $\mathrm{MoO}_{3}$ and $\mathrm{V}_{2} \mathrm{O}_{5}$ in particular, as well as for $\mathrm{NiO}, \mathrm{CuO}$, $\mathrm{Nd}_{2} \mathrm{O}_{3}, \mathrm{Eu}_{2} \mathrm{O}_{3}, \mathrm{Gd}_{2} \mathrm{O}_{3}$, and $\mathrm{Dy}_{2} \mathrm{O}_{3} . \mathrm{Tb}_{4} \mathrm{O}_{7}$ shows less irradiation-induced singlet oxygen production than water, although its absolute value is higher than water as it is so active on its own.

To help summarise the reactive oxygen species (ROS) data, the radiation-induced increase in each ROS is presented as a stacked bar chart (Fig. 4a). Because many of the metal oxide NPs contain very different atomic proportions of their metal element (e.g. $\mathrm{CuO}$ NPs are $50 \% \mathrm{Cu}$, while $\mathrm{MoO}_{3} \mathrm{NPs}$ are $25 \% \mathrm{Mo}$ ), we have replotted these data to normalise ROS values by stoichiometry to the metal proportion of each NP (Fig. 4b).

It is clear that superoxide is the main ROS produced by most irradiated NPs. The two exceptions are $\mathrm{V}_{2} \mathrm{O}_{5}$ and $\mathrm{MoO}_{3}$, where hydroxyl radicals are the majority ROS. For each $\mathrm{NP}$, singlet oxygen makes a very minor contribution. 

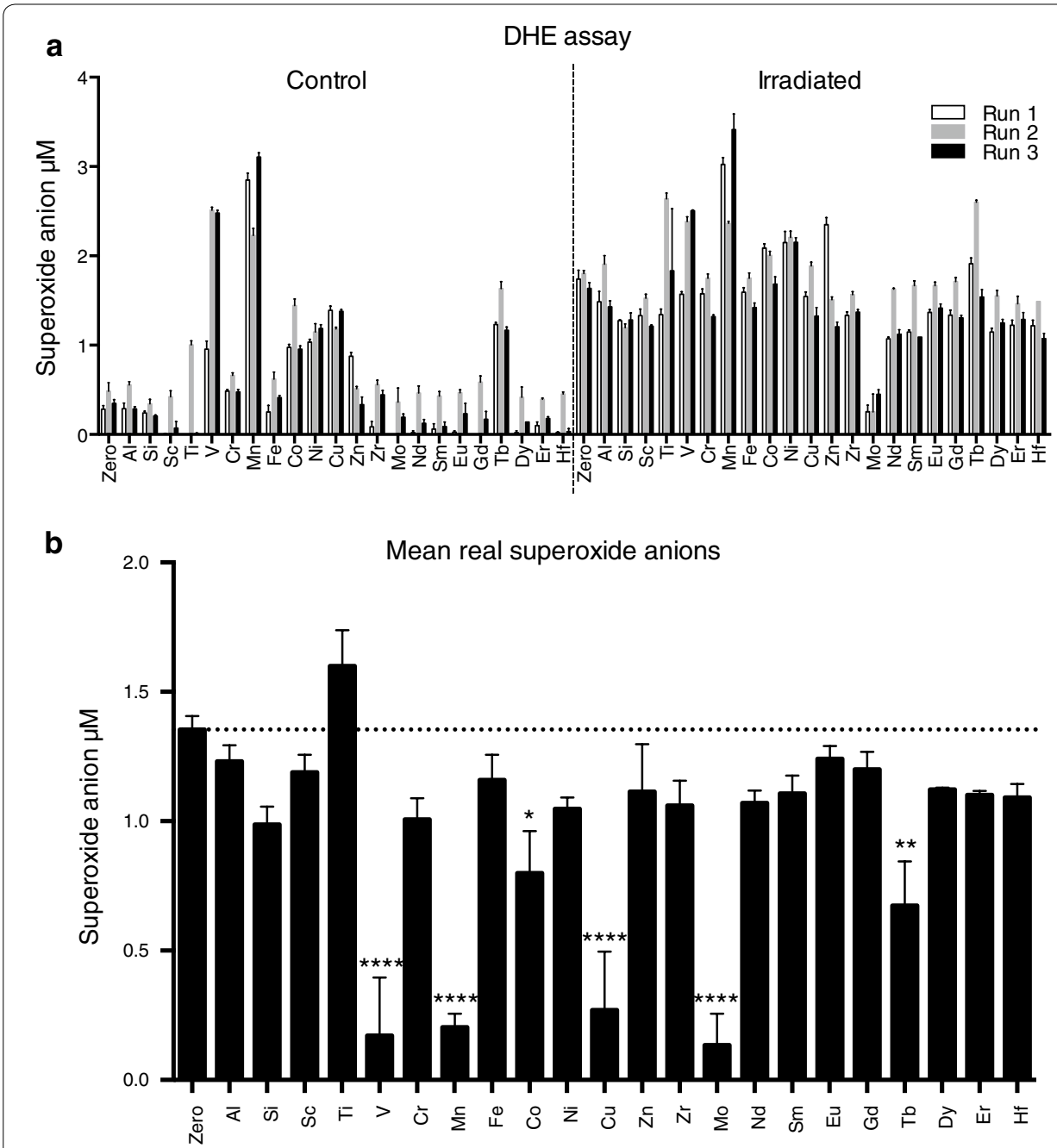

Fig. 2 Superoxide anion radical production. a Superoxide radical concentrations for unirradiated control (left side) and 10 Gy-irradiated (right side) NPs. Data are shown for three independent experiments (run 1, run 2, run 3). b Data from a replotted as 'real'values ( 10 Gy irradiated value minus 0 Gy control) \pm SEM. Dotted line shows the irradiation-induced increase due to water only. ${ }^{* * * *}$, ${ }^{* *}$ and ${ }^{*}$ denote, respectively, $P<0.0001$, $P<0.01$ and $P<0.05$ significant differences, compared to no NP (zero)

\section{Hole scavenger}

High-energy X-rays eject electrons from nanoparticles, leaving behind reactive holes with picosecond lifetimes that, unless already at the NP surface, are unlikely to take part in any reactions (Drescher et al. 2002). However, ejected electrons undergo subsequent collisions, sequentially lowering their energies to low eV levels (McMahon et al. 2011) where electron-hole $\left(\mathrm{e}^{-} / \mathrm{h}^{+}\right)$pairs can be formed in the metal oxides (Rodnyi 1997). If these migrate to the NP surface before recombining, they can participate in reactions with surface-adsorbed oxygen to generate superoxides from electrons and hydroxyl radicals from holes (Le Caër 2011; Sahu and Cates 2017).

To assess the possible role of X-ray-induced $\mathrm{e}^{-} / \mathrm{h}^{+}$pairs in superoxide formation by NPs, we repeated the superoxide assay in the presence of the hole scavenger $10 \mathrm{mM}$ formic acid (Puangpetch et al. 2011; Tan et al. 2003), or a pH-matched $10 \mathrm{mM}$ nitric acid 

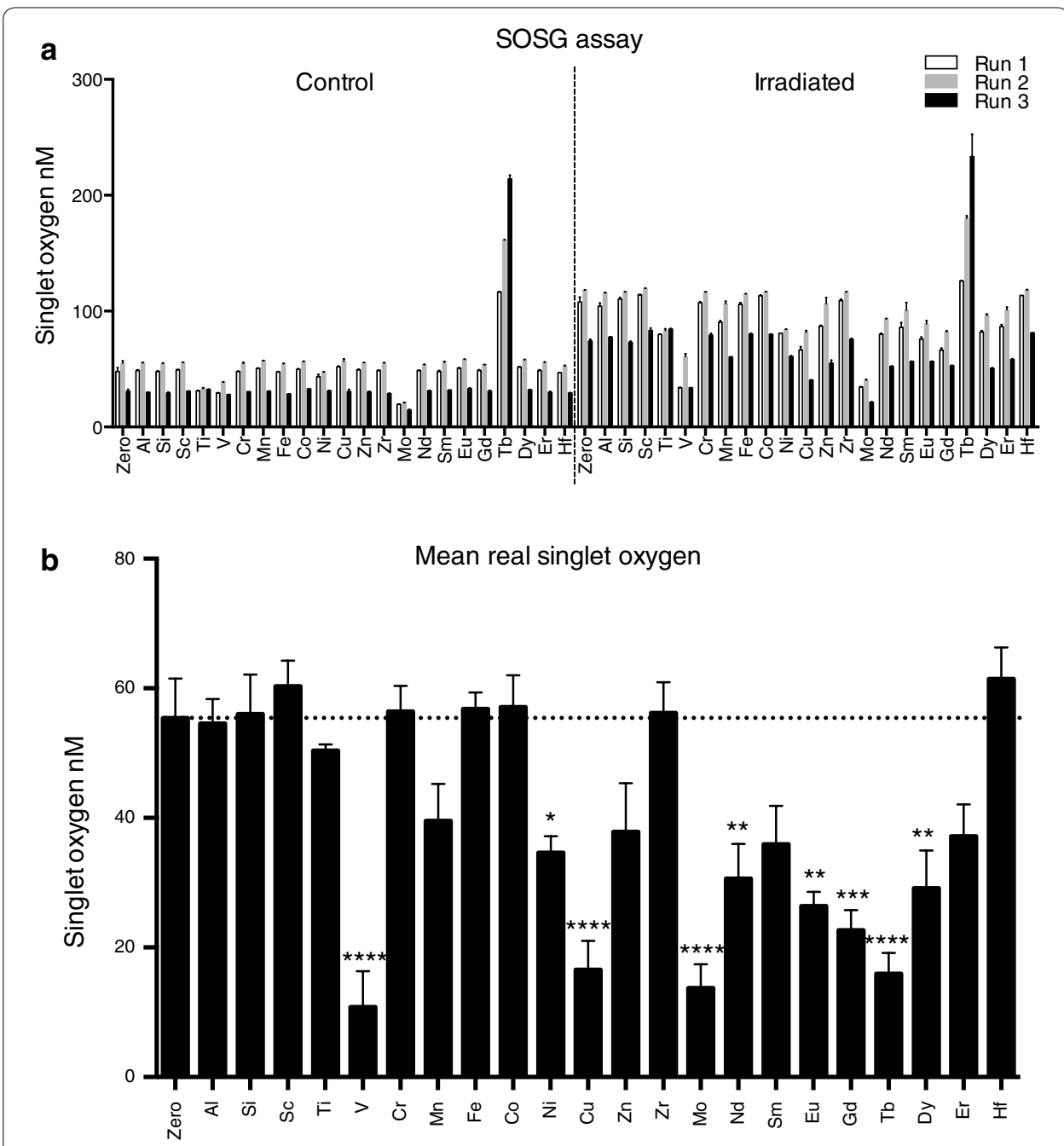

Fig. 3 Singlet oxygen production. a Singlet oxygen concentrations for unirradiated control (left side) and 10 Gy-irradiated (right side) NPs. Data are shown for 3 independent experiments (run 1, run 2, run 3). b Data from a replotted as 'real'values (10 Gy irradiated value minus $0 \mathrm{~Gy}$ control) \pm SEM. Dotted line shows the irradiation-induced increase due to water only. ${ }^{* * *},{ }^{* * *},{ }^{* *}$ and ${ }^{*}$ denote, respectively, $P<0.0001, P<0.001$, $P<0.01$ and $P<0.05$ significant differences, compared to no NP (zero)

control. If $\mathrm{e}^{-} / \mathrm{h}^{+}$pairs are important players in our experiments, then we expect the hole scavenger to increase the lifetime of the electrons, thus promoting superoxide formation at the NP surface.

Considering the non-irradiated control values, some differences between nitric acid and formic acid conditions are observed for $\mathrm{CuO}$ and $\mathrm{Tb}_{4} \mathrm{O}_{7}$, with $\mathrm{CuO}$ showing higher superoxides in formic acid and $\mathrm{Tb}_{4} \mathrm{O}_{7}$ showing less superoxide in formic acid. Similar results were observed for these metal oxides with irradiation. After irradiation, $\mathrm{MnO}_{2}$ also shows less superoxide formation in formic acid compared to in nitric acid. It is not clear why superoxide formation is lower in formic acid for these metal oxides.

After subtraction of the non-irradiated results, only $\mathrm{Fe}_{3} \mathrm{O}_{4}, \mathrm{CoO}, \mathrm{NiO}$ and $\mathrm{ZnO}$ demonstrated irradiation-dependent increases in superoxide radical generation in the presence of formic acid, compared with nitric acid (Fig. 5b). 


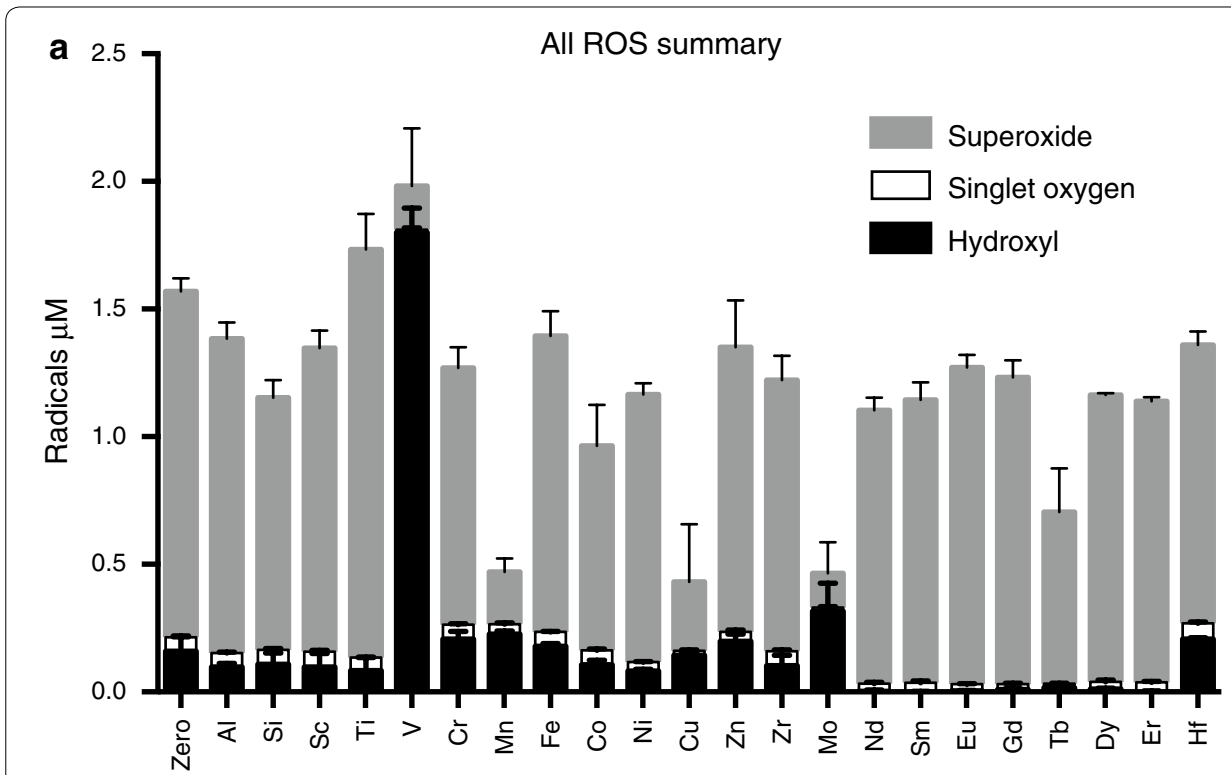

\section{b}

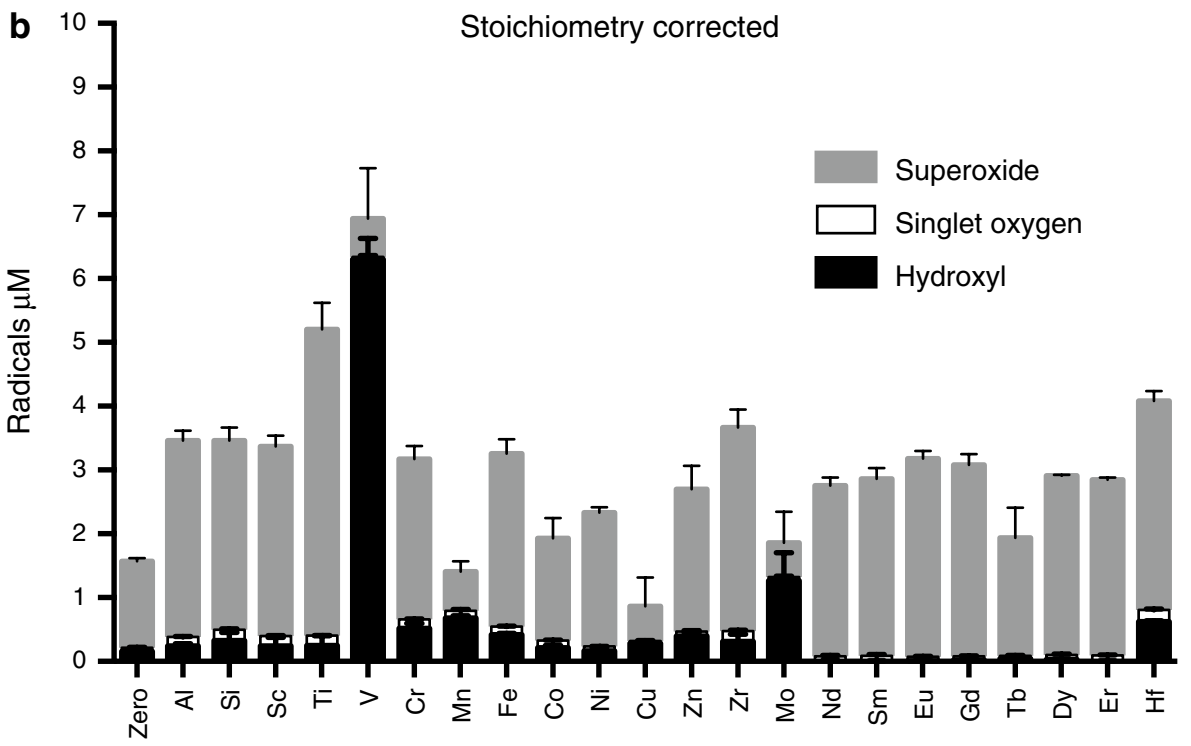

Fig. 4 a Stacked bar chart summarising the irradiation-induced ('real') change in overall radical production for each NP. $\mathbf{b}$ Data from a replotted to normalise the proportion of metallic element atoms, based on each NP chemical formula. Values for water (zero) left unaltered. All values \pm SEM

\section{DNA damage assay}

Plasmid DNA normally exists as a tightly wound supercoil. Single-strand breaks allow the supercoil to relax to an open circle which demonstrates slower migration on an electrophoretic gel. We therefore quantified DNA damage in the presence of NPs by measuring the proportion of relaxed circular DNA (Fig. 6).

In the absence of irradiation, $\mathrm{MoO}_{3}$ and $\mathrm{CuO}$ caused the greatest damage to DNA. These NPs also demonstrated the greatest DNA damage following irradiation (Fig. 6a-c).

When the DNA damage due to non-irradiated controls was subtracted from each irradiated value, it became clear that most NPs produced only slightly more 


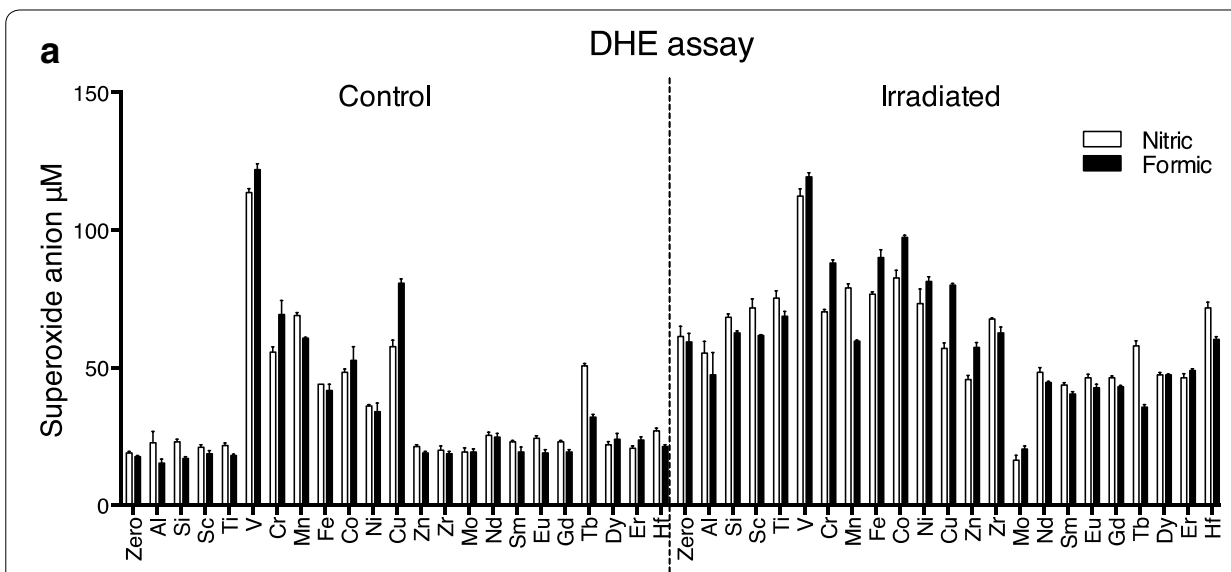

b

Mean real superoxide anions

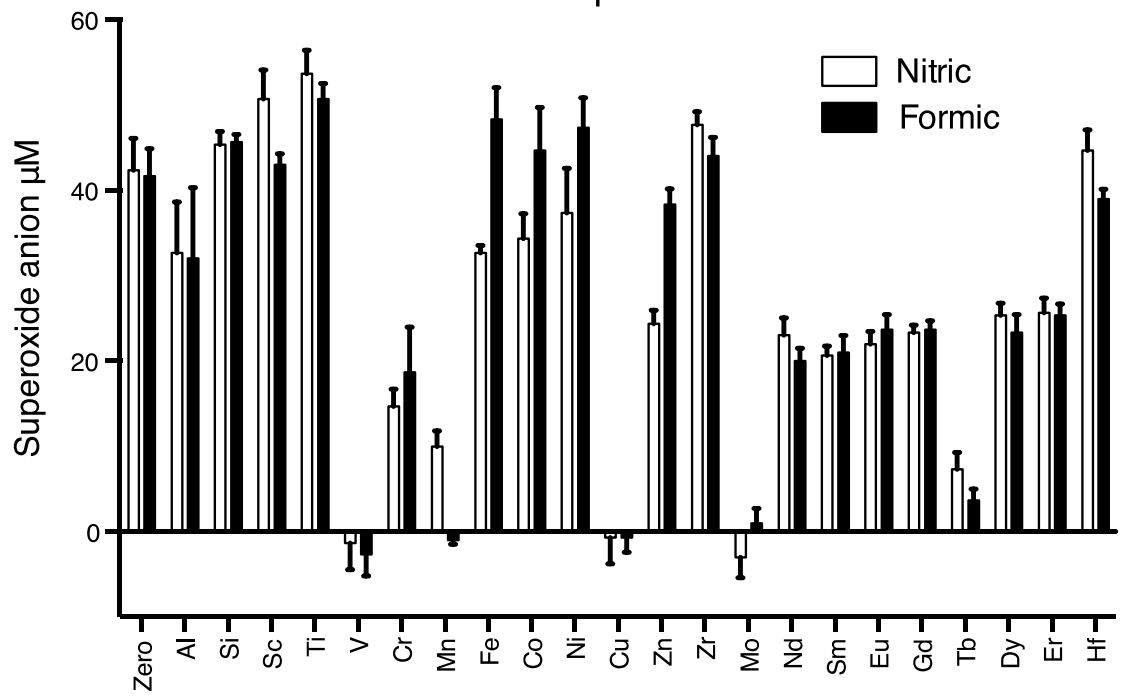

Fig. 5 a Superoxide formation in the presence of pH 3.510 mM nitric acid or pH 3.510 mM formic acid hole scavenger. Left side shows unirradiated controls and right side shows 10 Gy irradiated. $N=3$ and all values \pm SEM. $\mathbf{b}$ Data from a replotted as 'real'values (10 Gy irradiated value minus 0 Gy control) \pm SEM

irradiation-specific DNA damage than water (Fig. 6d). Only $\mathrm{CuO}$ performed significantly better than water in terms of irradiation-specific DNA damage (Fig. 6d).

\section{Discussion}

The ability of nanoparticles to act as $\mathrm{X}$-ray radiosensitisers has generally been viewed as a physical process, due to the increased absorption of X-rays, followed by ejection of secondary electrons (photoelectric effect) and fluorescence photons that then interact with water or biomolecules to produce radiolysis products, which include damaging radicals (Kuncic and Lacombe 2018). For this reason, the emphasis of NP radiosensitiser research has been on high atomic number elements, due to their expected greater interaction cross section with X-ray photons. 


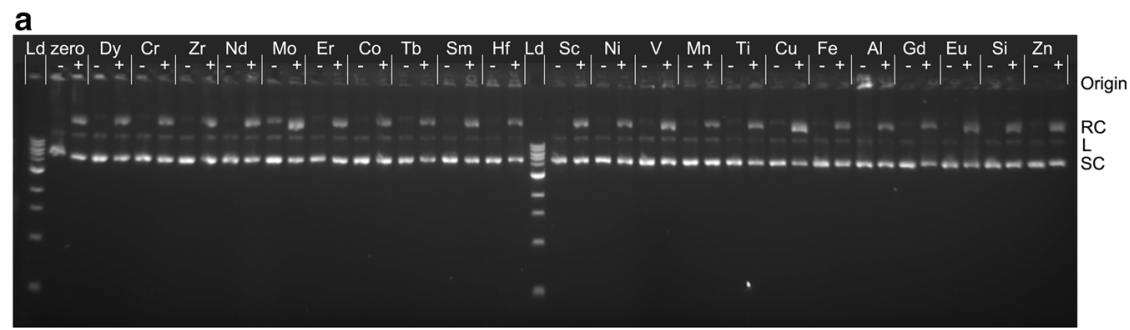

b

Relaxed circular DNA \%

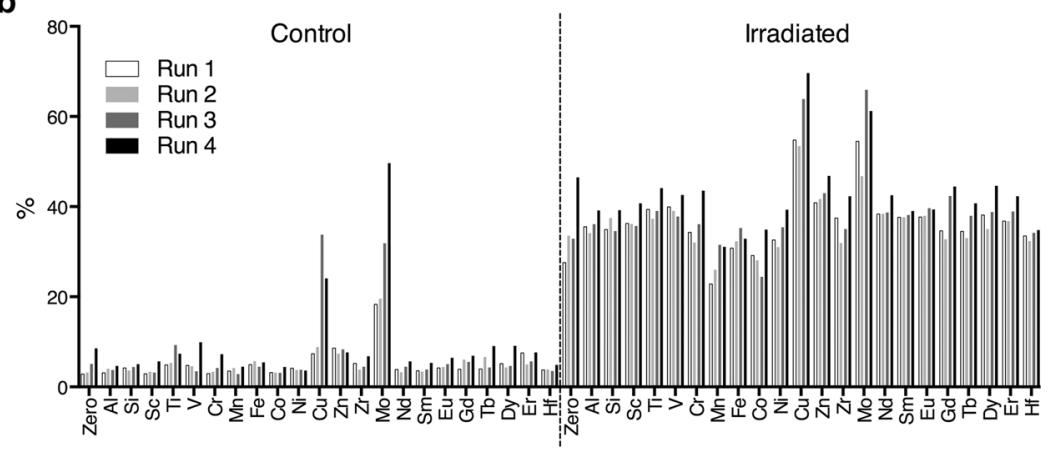

C

Mean relaxed circular DNA \%

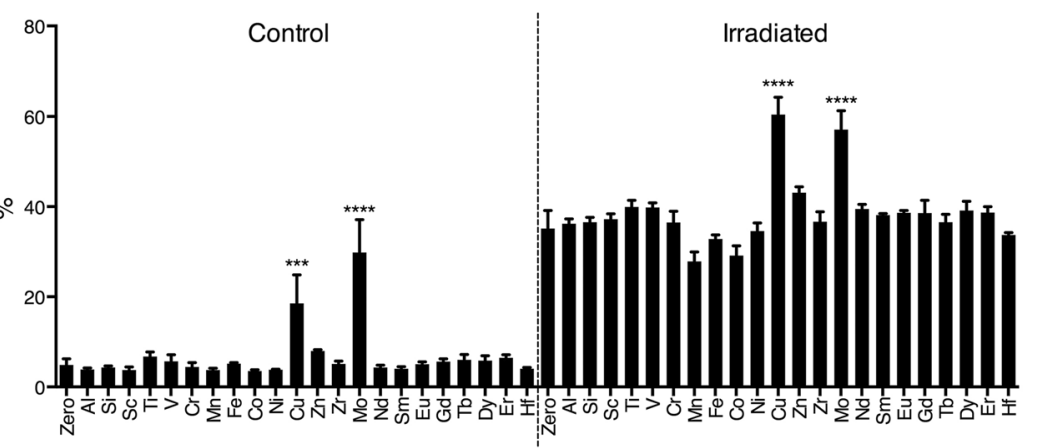

d

Mean real relaxed circular \%

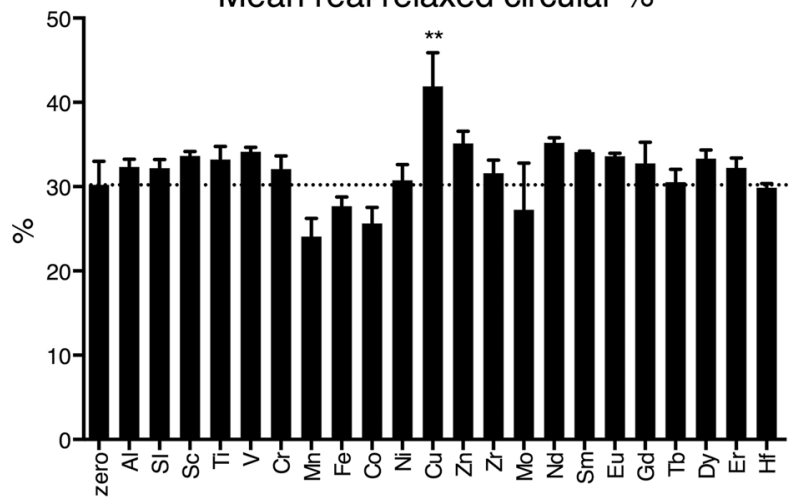

Fig. 6 DNA damage assays based on the appearance of the relaxed circular form of plasmid DNA. a Agarose gel from one experiment showing paired non-irradiated (-) and $10 \mathrm{~Gy}$ irradiated (+) samples. Bands corresponding to undamaged (supercoiled, SC), single-strand break (relaxed circular, RC) and double-strand break (linear, L) plasmid DNA are marked. Ld is $1 \mathrm{~kb}$ DNA ladder. Note that this gel is not loaded in atomic number order. $\mathbf{b}$ Percentage relaxed circular DNA from each experiment. $\mathbf{c}$ Average values from $\mathbf{b} \pm S E M$. $\mathbf{d}$ Data from c replotted as 'real'values ( $10 \mathrm{~Gy}$ irradiated value minus $0 \mathrm{~Gy}$ control) $\pm S E M$. Dotted line shows the irradiation-induced increase due to water only. ${ }^{* * * *}{ }^{* * *}$ and ${ }^{* *}$ denote, respectively, $P<0.0001, P<0.001$ and $P<0.01$ significant differences, compared to the respective no NP (zero) control 
A theoretical study by McMahon et al. (2016), based on physical processes, computed the energy deposition within $1 \mu \mathrm{m}$ around a series of X-ray-irradiated pure element $20 \mathrm{~nm}$ NPs in water $(Z=14$, Si to $Z=80, \mathrm{Hg})$. When all energy outputs are added together (Auger electrons, photoelectrons, Compton electrons, fluorescence, electron impact), the total energy deposition from 6-MV X-ray photons was relatively flat across all the elements studied (Fig. 3c, d in McMahon et al. 2016), implying that the choice of element makes little difference to the amount of ROS produced at these energies.

However, experimental data from Sicard-Rosselli et al. (2014) and Gilles et al. (2018) demonstrated that many more hydroxyl radicals (Gilles et al. 2018; SicardRoselli et al. 2014) and solvated electrons (Gilles et al. 2018) are produced from X-ray irradiated Au NPs than can be explained purely by physical processes, such as the photoelectric effect. They proposed that additional radicals are produced via reactions of secondary electrons with interfacial water molecules, that become stretched due to their adsorption to the Au NP and therefore require much less energy for $\mathrm{H}-$ $\mathrm{OH}$ bond radiolysis than bulk water (255 kJ/mol instead of $460 \mathrm{~kJ} / \mathrm{mol}$ ) (Liu 2013). This water distorting effect is not restricted to Au NPs: water molecules form similar structured layers up to $2 \mathrm{~nm}$ thick around any NP (Zobel 2016; Zobel et al. 2015) and this is where most radiolytic reactions are expected to occur.

Moreover, nanoparticles will inevitably come into contact with excited water $\left(\mathrm{H}_{2} \mathrm{O}^{*}\right)$ and ionised water $\left(\mathrm{H}_{2} \mathrm{O}^{+}, \mathrm{e}^{-}\right.$aq $)$, formed during the first $10^{-15} \mathrm{~s}$ of irradiation, plus the physico-chemical reaction products of these species, produced during the subsequent $10^{-12} \mathrm{~s}$, such as ${ }^{\circ} \mathrm{OH},{ }^{\circ} \mathrm{H}, \mathrm{H}_{3} \mathrm{O}^{+}$and $\mathrm{OH}^{-}$; and downstream products such as $\mathrm{H}_{2} \mathrm{O}_{2}$ (reviewed in Le Caër 2011). Because of their high surface area and specific surface chemistries, nanoparticles could catalyse many more reactions from these intermediates and thereby increase the overall concentration of radicals.

This mismatch between theory and experimental observations for Au NPs prompted us to consider if a broad range of metal oxide NPs, well known for their catalytic properties, but hitherto not considered as radiosensitisers because of their low atomic number, might be good radiosensitisers. We therefore experimentally compared the radical forming ability and DNA damage of 22 different metal oxides using clinically relevant 6-MV energy X-rays.

Two previous studies have compared the behaviour of several metal oxides under gamma irradiation. Chelnokov et al. (2014) measured yields of solvated electrons, relative to water, following radiolysis of concentrated metal oxide NP aqueous solutions in low oxygen conditions. Six of those NPs are in common with our study: $\mathrm{Al}_{2} \mathrm{O}_{3}, \mathrm{SiO}_{2}$, $\mathrm{ZnO}, \mathrm{Nd}_{2} \mathrm{O}_{3}, \mathrm{Sm}_{2} \mathrm{O}_{3}$, and $\mathrm{Er}_{2} \mathrm{O}_{3}$ (Chelnokov et al. 2014). At the lowest NP concentrations tested $(600 \mathrm{mM})$ Chelnokov found modest increases in solvated electrons for $\mathrm{Sm}_{2} \mathrm{O}_{3}$ (1.2-fold) and $\mathrm{Er}_{2} \mathrm{O}_{3}$ (1.4-fold), but no change for the other NPs tested. In normoxia, solvated electrons react with dissolved oxygen to give superoxide radicals, but we found no significant increases in superoxide for $\mathrm{Sm}_{2} \mathrm{O}_{3}$, and $\operatorname{Er}_{2} \mathrm{O}_{3}$. However, because Chelnokov's experiments were performed under argon, they are not directly comparable with ours.

Petrik et al. (2001) examined hydrogen production from a thin layer of adsorbed water on 28 different metal oxides during high dose gamma irradiation (0.1-1.5 M Gy), only 14 of which are in common with our study and are compared here. Hydrogen is mostly 
produced during water radiolysis from reactions of solvated electrons with water; but can be produced via reactions involving hydrogen radicals that generate hydroxyl radicals as a by-product $\left(\mathrm{H}_{2} \mathrm{O}^{*} \rightarrow{ }^{\circ} \mathrm{OH}+{ }^{\prime} \mathrm{H}\right.$, then $\left.{ }^{\prime} \mathrm{H}+{ }^{\prime} \mathrm{H} \rightarrow \mathrm{H}_{2}\right)$. Thus, a tentative link could be made between hydrogen production in that study and our measurements of hydroxyl radicals. Petrik et al. found an increased hydrogen yield relative to water with: $\mathrm{ZrO}_{2}, \mathrm{Nd}_{2} \mathrm{O}_{3}, \mathrm{Sm}_{2} \mathrm{O}_{3}, \mathrm{Eu}_{2} \mathrm{O}_{3}, \mathrm{Gd}_{2} \mathrm{O}_{3}, \mathrm{Er}_{2} \mathrm{O}_{3}$ and $\mathrm{HfO}_{2}$. Oxides that decreased hydrogen production relative to water were: $\mathrm{MnO}_{2}$ and $\mathrm{CuO}$. The other oxides Petrik et al. tested $\left(\mathrm{Al}_{2} \mathrm{O}_{3}, \mathrm{SiO}_{2}, \mathrm{TiO}_{2}, \mathrm{Cr}_{2} \mathrm{O}_{3}, \mathrm{NiO}\right.$ and $\left.\mathrm{ZnO}\right)$ showed no difference in hydrogen production.

We find no significant irradiation-induced changes in hydroxyl radicals for any of these metal oxides. Indeed, our trend of decreased hydroxyl radicals for the lanthanides is opposite to the increased hydrogen production data of Petrik et al.

Therefore, either the hydrogen radical-mediated pathway is such a minor player in the overall reactions that it is easily swamped by independent reactions and/or there are fundamental differences in the experimental designs. To address the second point, the most obvious difference is that Petrik et al. exposed metal oxides to water vapour, to form a thin adsorbed layer, whereas we irradiate NPs in solution. Our protocol therefore allows two additional sets of reactions to occur. Firstly, energetic secondary electrons ejected from NPs can travel further in bulk water and participate in more reactions than is possible in a thin adsorbed layer of water. Secondly, NPs can migrate through bulk water, coming into contact with radiolytically produced hydrogen peroxide and metastable radiolysis species, which they catalytically convert into various radicals (Le Caër 2011; Lousada et al. 2013). Moreover, for some of these catalytic reactions, the NP surface is not necessarily required. Metal ions released from NPs, such as $\mathrm{V}^{3+}$, readily participate in Fenton-like catalytic reactions with hydrogen peroxide to generate hydroxyl radicals and hydroperoxide radicals (Du and Espenson 2005).

Electron donation to singlet oxygen can generate superoxide anions (Saito et al. 1983) and, perhaps because of this, we find a partial correlation in our data between radiation-induced superoxide and singlet oxygen levels. Thus, the lowest levels of superoxide and singlet oxygen compared to non-irradiated values are seen with: $\mathrm{V}_{2} \mathrm{O}_{5}, \mathrm{CuO}, \mathrm{MoO}_{3}$, $\mathrm{Tb}_{4} \mathrm{O}_{7}$. Although $\mathrm{MnO}_{2}$ does not fit this pattern, being very low with superoxide, but only slightly lowered with singlet oxygen. However, no strong correlation exists between high levels of superoxide and singlet oxygen.

Although superoxides can produce hydroxyl radicals via Fenton-like electron reduction of hydrogen peroxide (Richmond et al. 1981), our data show no consistent correlation between radiation-induced superoxide and hydroxyl radical levels.

Regarding the correlation of ROS levels to DNA damage, we summarise our data in Table 2.

Our data suggest that $\mathrm{TiO}_{2}$ and $\mathrm{V}_{2} \mathrm{O}_{5}$ NPs are worth further investigation, because of consistent increases in both ROS and DNA damage. However, various surprises should also be explored. Notably, $\mathrm{Sc}_{2} \mathrm{O}_{3}, \mathrm{ZnO}, \mathrm{Nd}_{2} \mathrm{O}_{3}, \mathrm{Sm}_{2} \mathrm{O}_{3}, \mathrm{Eu}_{2} \mathrm{O}_{3}, \mathrm{Dy}_{2} \mathrm{O}_{3}$ and especially $\mathrm{CuO}$, produced more irradiation-induced DNA damage than expected from their total irradiation-induced ROS output.

$\mathrm{CuO}$ NPs cause DNA damage in vivo (Atha et al. 2012). Specifically, copper ions form adducts with DNA that cause structural distortions (Abdelhamid et al. 2018) and potentiate ROS-mediated damage (Cervantes-Cervantes et al. 2005). $\mathrm{CuO}$ is therefore likely 
Table 2 Summary table of total irradiation induced: ROS, DNA damage and $\mathrm{e}^{-} / \mathrm{h}^{+}$pair formation

\begin{tabular}{|c|c|c|c|}
\hline NP & ROS & DNA damage & $\mathrm{e}^{-} / \mathrm{h}^{+}$pair \\
\hline $\mathrm{V}_{2} \mathrm{O}_{5}$ & ++ & + & \\
\hline $\mathrm{TiO}_{2}$ & + & + & \\
\hline $\mathrm{Al}_{2} \mathrm{O}_{3}$ & - & & \\
\hline $\mathrm{Sc}_{2} \mathrm{O}_{3}$ & - & + & \\
\hline $\mathrm{Cr}_{2} \mathrm{O}_{3}$ & - & & \\
\hline $\mathrm{Fe}_{3} \mathrm{O}_{4}$ & - & & ++ \\
\hline $\mathrm{ZnO}$ & - & + & ++ \\
\hline $\mathrm{ZrO}_{2}$ & - & & \\
\hline $\mathrm{Eu}_{2} \mathrm{O}_{3}$ & - & + & \\
\hline $\mathrm{Gd}_{2} \mathrm{O}_{3}$ & - & & \\
\hline $\mathrm{HfO}_{2}$ & - & & \\
\hline $\mathrm{SiO}_{2}$ & -- & & \\
\hline $\mathrm{CoO}$ & -- & - & ++ \\
\hline $\mathrm{NiO}$ & -- & & ++ \\
\hline $\mathrm{Nd}_{2} \mathrm{O}_{3}$ & -- & + & \\
\hline $\mathrm{Sm}_{2} \mathrm{O}_{3}$ & -- & + & \\
\hline $\mathrm{Dy}_{2} \mathrm{O}_{3}$ & -- & + & \\
\hline $\mathrm{Er}_{2} \mathrm{O}_{3}$ & -- & & \\
\hline $\mathrm{MnO}_{2}$ & --- & - & \\
\hline CuO & --- & ++ & \\
\hline $\mathrm{MoO}_{3}$ & --- & & \\
\hline $\mathrm{Tb}_{4} \mathrm{O}_{7}$ & --- & & \\
\hline
\end{tabular}

Ranked from high to low ROS and for similar levels of damage, ranked in element order. Change from control: $+/-=10-25 \% ;++/--=25-50 \% ;+++/---=>50 \%$

to potentiate irradiation-induced DNA damage, without itself producing ROS and this could explain the mismatch between our DNA damage and ROS data for $\mathrm{CuO}$.

The extent of NP-DNA interaction is likely to be an important variable for all the other NPs studied, since the radiation dose deposited near the NP increases exponentially as the NP surface is approached. Thus, in the interaction of $2 \mathrm{~nm}$ AuNPs with 6-MV X-ray photons, the dose can be enhanced several 1000-fold within $10 \mathrm{~nm}$ of the Au surface (McMahon et al. 2011). It is therefore likely that the binding of NPs to DNA, especially if these interactions physically destabilise DNA, will result in much greater irradiation damage. Conversely, NPs that do not make close contact with DNA will likely result in less DNA damage than predicted from their ROS output.

Of course, many of the NPs we have tested are far too toxic in their current formulation to be considered for direct translation to preclinical studies. NPs can be toxic via multiple parallel mechanisms (reviewed in Sukhanova et al. 2018; Huang et al. 2017). These include: physical damage to membranes and organelles, disruption of membrane channels and biochemical reactions (Taggart et al. 2016), activation of death pathways (Tzelepi et al. 2019) and generation of ROS stress (Manke et al. 2013). In addition to their toxicity, many rare earth metal oxides also present fire and explosion hazards (Rim et al. 2013).

Of the two NPs we have identified as good radiosensitisers $\left(\mathrm{V}_{2} \mathrm{O}_{5}\right.$ and $\left.\mathrm{TiO}_{2}\right)$, only $\mathrm{TiO}_{2}$ is of sufficiently low toxicity to consider following up. Indeed, some advances have 
already been made using radiosensitisers based on $\mathrm{TiO}_{2}$ NPs (Nakayama et al. 2016; Morrison et al. 2017; Townley et al. 2012).

We consider that the future of NP radiosensitisers most probably lies in the combination of high $Z$ elements with catalytic oxides: using the photoelectric effect of high $Z$ elements to feed secondary electrons into the catalyst. These composite NPs could be made as complex oxides, as has been done with $\mathrm{Bi}_{2} \mathrm{WO}_{6}$ (Sahu and Cates 2017); aggregate mixtures, or core-shell arrangements. For instance, improved radiosensitisation has been reported using lanthanide-doped $\mathrm{TiO}_{2}$ (Townley et al. 2012) and $\mathrm{ZnO}$ NPs (Ghaemi et al. 2016), $\mathrm{ZnO}-\mathrm{SiO}_{2}$ nanocomposites (Generalov et al. 2015) and $\mathrm{Au}-\mathrm{Bi}_{2} \mathrm{~S}_{3}$ heterostructures (Wang et al. 2019).

As with all catalysts, it will be important to consider ways to prevent 'fouling' of the catalytic surface by ligands or serum proteins in vitro, since we and others have previously shown that the presence of a ligand shell on AuNPs greatly decreases irradiationinduced ROS production (Gilles et al. 2014; Grellet et al. 2017).

\section{Conclusions}

We find large variations in the formation of three types of radical species in solutions of metal oxide NPs. In general, the largest irradiation-induced increases are seen for superoxides, where $\mathrm{TiO}_{2}$ produces an additional $1.6 \mu \mathrm{M}$ superoxide upon irradiation; this being some $0.2 \mu \mathrm{M}$ more than water only. A more impressive increase is seen for hydroxyl radicals using $\mathrm{V}_{2} \mathrm{O}_{5}$, demonstrating an additional $1.8 \mu \mathrm{M}$ hydroxyl radicals upon irradiation; $1.6 \mu \mathrm{M}$ more than water only. However, bulk radical formation per se does not predict the extent of radiation-induced DNA damage in the presence of these NPs. Thus, although $\mathrm{TiO}_{2}$ and $\mathrm{V}_{2} \mathrm{O}_{5}$ both produce more irradiation-induced DNA damage than water, $\mathrm{CuO}$ produces nearly $8 \%$ more DNA damage even though it shows one of the lowest irradiation-induced increases in radicals. Therefore, other factors that probably involve intimate DNA-NP interactions, such as DNA destabilisation and highly localised increases in radical concentration near the NP surface, likely predominate.

In summary, when considering NP radiosensitisers, it is perhaps worth remembering the old phrase 'don't judge a book by its cover'. Theoretical predictions of energy output and biological damage are currently based on physical principles and need to be expanded to take account of subsequent chemical reactions on and near the NP surface.

Also, the purely catalytic nature of many NPs, within a 'sea' of radiolytic reactants needs to be considered in order to obtain a fuller picture of the intrinsic radiosensitising ability of a NP. These physical/chemical considerations then need to be put into a biological context. How well are they taken up by cells and is there any selectivity towards cancer cells? Once the NPs are in a biological medium of proteins and sugars, does this alter their ability to produce ROS and damage cancer cells? We know that our results pose more questions than they answer, but if this leads to a deeper understanding of radiosensitisation theory and allows for rational choices of the best nanoparticle materials, then this is ultimately a good thing. 


\section{Methods}

\section{Nanoparticles}

The following nanoparticles were obtained from US Research Nanomaterials: $\mathrm{Cr}_{2} \mathrm{O}_{3}$ (US3060, $60 \mathrm{~nm},>99 \%$ ), $\mathrm{MnO}_{2}$ (US3319NMP, $50 \mathrm{~nm}, 98 \%$ ), CoO (US3051, $50 \mathrm{~nm}, 99.7 \%$ ), $\mathrm{ZrO}_{2}$ (US3600, $40 \mathrm{~nm},>99 \%$ ), $\mathrm{MoO}_{3}$ (US3330, 13-80 nm, 99.94\%), $\mathrm{Nd}_{2} \mathrm{O}_{3}$ (US3350, 30-45 nm, 99.9\%), $\mathrm{Sm}_{2} \mathrm{O}_{3}$ (US3450, 15-45 nm, 99.95\%), $\mathrm{Eu}_{2} \mathrm{O}_{3}$ (US3543, 10-100 nm, 99.99\%), $\mathrm{Gd}_{2} \mathrm{O}_{3}$ (US3240, 10-100 nm, 99.9\%), $\mathrm{Tb}_{4} \mathrm{O}_{7}$ (US3455, 10-100 nm, 99.99\%), $\mathrm{Dy}_{2} \mathrm{O}_{3}$ (US3080, $\left.30 \mathrm{~nm},>99.9 \%\right), \mathrm{Er}_{2} \mathrm{O}_{3}$ (US3140, 10-100 nm, 99.9\%) and $\mathrm{HfO}_{2}$ (US3245, 61-80 nm, 99.99\%).

The following nanoparticles were obtained from Sigma-Aldrich: $\mathrm{Al}_{2} \mathrm{O}_{3}$ (544833, <50 nm, 99.8\%), $\mathrm{SiO}_{2}$ (637238, 10-20 nm, 99.5\%), $\mathrm{TiO}_{2}$ (718467, $21 \mathrm{~nm}, 99.5 \%$ ), $\mathrm{Fe}_{3} \mathrm{O}_{4}$ (637106, 50-100 nm, 97\%), $\mathrm{NiO}$ (637130, <50 nm, 99.8\%), $\mathrm{CuO}$ (544868, $<50 \mathrm{~nm}, 82.6 \%)$ and $\mathrm{ZnO}(721077,<100 \mathrm{~nm})$.

$\mathrm{Sc}_{2} \mathrm{O}_{3}$ was obtained from American Elements (SC-OX-02-NP, < $80 \mathrm{~nm}, 99 \%$ ).

$\mathrm{V}_{2} \mathrm{O}_{5}$ was obtained from Nanoshel (NS6130-03-399, < $80 \mathrm{~nm}, 99.9 \%$ ).

\section{TEM}

Samples were prepared by drop-coating films of the NP solutions on electrostatically discharged carbon-coated copper TEM grids and visualised on a JEM-1400 model EM instrument (JEOL, USA) operated at an accelerating voltage of $80 \mathrm{kV}$ and $\times 30,000 \mathrm{mag}$ nification. Size histograms were measured from 20 TEM images per nanoparticle type at $\times 3000$ magnification using the Analyze Particles feature of Image J software (version $1.52 ; \mathrm{NIH})$ and are reported as the mean and median values.

DLS

The hydrodynamic diameter of $2.5 \mathrm{mM}$ NPs in 3\% PBS pH 7.4 was measured using a Nanotrac Flex particle size analyser, with Flex 11.1.0.5 software (Microtrac).

$X R D$

Samples were analysed using a Siemens D5005 XRD with a long fine focus copper X-ray tube energised at $40 \mathrm{kV}$ and $40 \mathrm{~mA}$, running conventional Bragg-Brentano geometry. Most runs were $0.5 \mathrm{~s} / \mathrm{step}$, with some at $8 \mathrm{~s} / \mathrm{step}$. Crystal phases were determined from XRD spectra using QualX2 software (Altomare et al. 2015) (version 2.24; Institute of Crystallography CNR, Bari, Italy) and PowCod database 1901.

\section{Hydroxyl radical probe}

$5 \mathrm{mM}$ stock of coumarin-3-carboxylic acid (CCA) powder (Sigma-Aldrich) was prepared in $6 \%$ PBS pH 7.4 .

\section{Singlet oxygen probe}

Singlet oxygen sensor green (SOSG) was purchased from ThermoFisher. From a $5 \mathrm{mM}$ methanolic stock, a working solution of $1 \mu \mathrm{M}$ was prepared in 6\% $\mathrm{PBS} \mathrm{pH}$ 7.4. 


\section{Superoxide anion probe}

Dihydroethidium (DHE) was purchased from ThermoFisher. From a stock of $20 \mathrm{mM}$ DHE in DMSO, a working solution of $50 \mu \mathrm{M}$ was prepared in 6\% PBS pH 7.4.

\section{Radical measurement}

Experiments were run a minimum of three times independently and each time containing technical triplicates. Fifty microlitres of probe working solution was added to $50 \mu \mathrm{l}$ of 5 mM NP in deionised water in black-walled 96-well plates (Cellstar, Greiner), producing a $2.5 \mathrm{mM}$ NP working solution. After irradiation, the fluorescence of each well was measured using a FLUOstar Optima plate reader (BMG Labtech), according to the type of probe: CCA at Ex $390 \mathrm{~nm} / \mathrm{Em} 450 \mathrm{~nm}$, SOSG at Ex $485 \mathrm{~nm} / \mathrm{Em} 520 \mathrm{~nm}$, and DHE at Ex 485 nm/Em 590 nm (Zhao et al. 2003).

\section{Radical probe calibration curves}

Each NP could potentially alter the fluorescence of the probe solution. Therefore, for each probe, $50 \mu \mathrm{l}$ serial dilutions of the fully oxidised fluorescence molecule in 6\% PBS were mixed with $50 \mu \mathrm{l} 5 \mathrm{mM}$ NP solution and the fluorescence measured as already described.

For CCA calibration, 7-hydroxycoumarin-3-carboxylic acid (7OH-CCA, SigmaAldrich) was used. For SOSG calibration, $0.5 \mu \mathrm{M}$ SOSG was reacted with $6 \% \mathrm{H}_{2} \mathrm{O}_{2}$ and $2 \% \mathrm{NaOCl}$. For DHE calibration, $1.5 \mu \mathrm{M}$ DHE was reacted with $0.5 \mathrm{mM}$ xanthine in $0.9 \%$ $\mathrm{NaCl}$ and $10 \mathrm{mU} / \mathrm{ml}$ xanthine oxidase (Sigma-Aldrich). We report the molarity of each radical species, assuming an equimolar reaction between each probe and its cognate radical.

\section{Hole quenching}

Fifty microlitres of $5 \mathrm{mM}$ NP solutions were mixed with $50 \mu \mathrm{l}$ of $50 \mu \mathrm{M}$ DHE in either $10 \mathrm{mM}$ formic acid pH 3.5 as a hole scavenger (Puangpetch et al. 2011; Tan et al. 2003) or $10 \mathrm{mM}$ nitric acid pH 3.5 as a control.

Samples were irradiated in 96-well plates, as described and fluorescence measured at Ex 485 nm/Em $590 \mathrm{~nm}$, as described.

\section{Plasmid DNA damage assay}

Plasmid pBR322 was extracted from bacteria using Qiagen plasmid midi kits and kept as a $50 \mathrm{ng} / \mu \mathrm{l}$ stock in $10 \mathrm{mM}$ Tris $-\mathrm{HCl}, \mathrm{pH}$ 8.5. Ten microlitres of plasmid DNA were mixed with $10 \mu \mathrm{l}$ of $5 \mathrm{mM} \mathrm{NP}$ solution in 96-well plates. Solutions were either left untreated or irradiated with $10 \mathrm{~Gy}$ of 6-MV X-rays, as described below. Five microlitres of each sample were mixed with 5- $\mu$ l loading dye (Purple, New England Biolabs) and loaded onto $1 \%$ agarose electrophoresis gels containing $0.2 \mu \mathrm{g} / \mathrm{ml}$ ethidium bromide with a running buffer of Tris-borate-EDTA with $0.2 \mu \mathrm{g} / \mathrm{ml}$ ethidium bromide. A $1 \mathrm{~kb}$ DNA ladder was also used (Quick-load Purple Plus, New England Biolabs). Gels were run at $110 \mathrm{~V}$ for $1 \mathrm{~h}$ and then photographed using a G:Box Chemi XX6 gel documentation 
system (Syngene), ensuring that no image pixels were saturated. DNA band intensities were quantified using the Gel Analysis feature of ImageJ software (version 1.52; NIH).

\section{$X$-ray irradiation}

Plates were sandwiched between two blocks of $10-\mathrm{cm}$ solid water shielding (Gammex) to simulate the location of a deep tumour and X-rays were deposited within the liquid in each well by beam shaping, using a treatment plan based on CT scans of the plates. Plates were irradiated with 10 Gy of 6-MV X-rays at a dose rate of 5 Gy/min using a clinical linear accelerator (Versa HD, Elekta) at GenesisCare, Milton Keynes. The radiation field was $25 \times 25 \mathrm{~cm}$ and previous calculations with a similar linear accelerator machine have shown that this field size, with $10 \mathrm{~cm}$ depth of water and 6-MV photons will produce a broad polychromatic energy spectrum from 0 to $6 \mathrm{MV}$, with the majority of the photon energies below $1 \mathrm{MeV}$ (Konefal et al. 2015).

\section{Statistical analysis}

Data from three independent experiments were compared to the no NP control using one-way ANOVA with Dunnett's multiple comparisons (GraphPad Prism v6 software).

\section{Supplementary information}

Supplementary information accompanies this paper at https://doi.org/10.1186/s12645-019-0057-9.

Additional file 1: Figure S1. NP TEM images (low and high magnification) and size histograms.

Additional file 2: Figure S2. DLS data of $2.5 \mathrm{mM} \mathrm{NPs}$ in 3\% PBS.

Additional file 3: Figure S3. XRD scans and matches to PowCod database.

Additional file 4. Excel spreadsheet of raw fluorescence data, plus graphs; and fluorescence-to-molarity calibration curves using different concentrations of oxidised probes.

\section{Abbreviations}

NP: nanoparticle; TEM: transmission electron microscopy; DLS: dynamic light scattering; XRD: X-ray diffraction; CCA coumarin-3-carboxylic acid; SOSG: singlet oxygen sensor green; DHE: dihydroethidium; 7OH-CCA: 7-hydroxycoumarin3-carboxylic acid; ROS: reactive oxygen species; $\mathrm{e}^{-} / \mathrm{h}^{+}$: electron/hole; $Z$ : atomic number.

\section{Acknowledgements}

We thank the radiographers at Genesis Care, Milton Keynes for help with irradiations.

We also thank colleagues at the Open University for technical assistance: Dr Igor Kraev for help with TEM, George Bryant for help with DLS and Dr Matthew Kershaw for help with XRD. Additional thanks to Open University undergraduate students Heather Walsh and Heather Allderidge for pilot work developing radical assays with $\mathrm{TiO}_{2}$ nanoparticles.

\section{Authors' contributions}

AG performed all of the experiments and contributed to study design and data analysis. JG was the primary supervisor and designed the study and data analysis. NC and EC were members of the supervision team and contributed to study design and data analysis. All authors read and approved the final manuscript.

\section{Funding}

This work was funded by grants from the Sir John Mason Academic Trust and Santander Bank. Alexandra Guerreiro is a PhD candidate in the New University of Lisbon RaBBiT doctoral training program and her stipend was provided by Fundação para a Ciências e Tecnologia (FCT/MCTES), Radiation Biology and Biophysics Doctoral Training Programme (RaBBiT, PD/00193/2012); UID/Multi/04378/2013 (UCIBIO); UID/FIS/00068/2013 (CEFITEC); and grant number PD/ $\mathrm{BD} / 114450 / 2016$ to Alexandra Guerreiro. None of the funding bodies played any role in the study design, data collection and analysis, or writing of the manuscript.

\section{Availability of data and materials}

The datasets for the ROS assays are included in the additional information file. All other datasets are available from the corresponding author on reasonable request.

Ethics approval and consent to participate Not applicable. 


\section{Consent for publication}

Not applicable.

\section{Competing interests}

The authors declare that they have no competing interests.

\section{Author details}

${ }^{1}$ Faculty of Science and Technology, New University of Lisbon, Lisbon, Portugal. ${ }^{2}$ School of Life, Health and Chemical Sciences, The Open University, Milton Keynes, UK.

Received: 27 September 2019 Accepted: 10 December 2019

Published online: 19 December 2019

\section{References}

Abdelhamid MA, Fábián L, MacDonald CJ, Cheesman MR, Gates AJ, Waller ZA. Redox-dependent control of i-Motif DNA structure using copper cations. Nucleic Acids Res. 2018;46(12):5886-93.

Algethami M. Radiation dose enhancement using $\mathrm{Bi}_{2} \mathrm{~S}_{3}$ nanoparticles in cultured mouse $\mathrm{PC} 3$ prostate and $\mathrm{B} 16$ melanoma cells. NanoWorld J. 2015;1 (3):99-104

Altomare A, Corriero N, Cuocci C, Falcicchio A, Moliterni A, Rizzi R. QUALX2.0: a qualitative phase analysis software using the freely available database POW-COD. J. Appl. Crystallogr. 2015;48(2):598-603.

Atha DH, Wang H, Petersen EJ, Cleveland D, Holbrook RD, Jaruga P, et al. Copper oxide nanoparticle mediated DNA damage in terrestrial plant models. Environ Sci Technol. 2012;46(3):1819-27.

Azzam El, Jay-Gerin JP, Pain D. lonizing radiation-induced metabolic oxidative stress and prolonged cell injury. Cancer Lett. 2012;327(1-2):48-60.

Baskar R, Dai J, Wenlong N, Yeo R, Yeoh K-W. Biological response of cancer cells to radiation treatment. Front Mol Biosci. 2014;1:24. https://doi.org/10.3389/fmolb.2014.00024

Carrasco-Flores EA, LaVerne JA. Surface species produced in the radiolysis of zirconia nanoparticles. J Chem Phys. 2007;127(23):234703.

Cervantes-Cervantes MP, Calderón-Salinas JV, Albores A, Muñoz-Sánchez JL. Copper increases the damage to DNA and proteins caused by reactive oxygen species. Biol Trace Elem Res. 2005;103(3):229-48.

Chelnokov E, Cuba V, Simeone D, Guigner J-M, Schmidhammer U, Mostafavi M, et al. Electron transfer at oxide/water interfaces induced by ionizing radiation. J Phys Chem C. 2014;118(15):7865-73.

Chu S-H, Karri S, Ma Y-B, Feng D-F, Li Z-Q. In vitro and in vivo radiosensitization induced by hydroxyapatite nanoparticles. Neuro Oncol. 2013;15(7):880-90.

David Gara PM, Garabano NI, Llansola Portoles MJ, Moreno MS, Dodat D, Casas OR, et al. ROS enhancement by silicon nanoparticles in X-ray irradiated aqueous suspensions and in glioma C6 cells. J Nanoparticle Res. 2012;14(3):741.

Drescher M, Hentschel M, Kienberger R, Uiberacker M, Yakovlev V, Scrinzi A, et al. Time-resolved atomic inner-shell spectroscopy. Nature. 2002;419:803-7.

Du G, Espenson JH. Oxidation of Vanadium(III) by hydrogen peroxide and the oxomonoperoxo vanadium(V) Ion in acidic aqueous solutions: a kinetics and simulation study. Inorg Chem. 2005;44(15):5514-22.

Generalov R, Kuan WB, Chen W, Kristensen S, Juzenas P. Radiosensitizing effect of zinc oxide and silica nanocomposites on cancer cells. Colloids Surf B Biointerfaces. 2015;129:79-86.

Ghaemi B, Mashinchian O, Mousavi T, Karimi R, Kharrazi S, Amani A. Harnessing the cancer radiation therapy by Lanthanide-doped zinc oxide based theranostic nanoparticles. ACS Appl Mater Interfaces. 2016;8(5):3123-34.

Gilles M, Brun E, Sicard-Roselli C. Gold nanoparticles functionalization notably decreases radiosensitization through hydroxyl radical production under ionizing radiation. Colloids Surf B Biointerfaces. 2014;123:770-7.

Gilles M, Brun E, Sicard-Roselli C. Quantification of hydroxyl radicals and solvated electrons produced by irradiated gold nanoparticles suggests a crucial role of interfacial water. J Colloid Interface Sci. 2018:525:31-8.

Grellet S, Tzelepi K, Roskamp M, Williams P, Sharif A, Slade-Carter R, et al. Cancer-selective, single agent chemoradiosensitising gold nanoparticles. PLoS ONE. 2017;12(7):e0181103.

Haume K, Rosa S, Grellet S, Śmiałek MA, Butterworth KT, Solov'yov AV, et al. Gold nanoparticles for cancer radiotherapy: a review. Cancer Nanotechnol. 2016:7(1):8.

Huang Y-W, Cambre M, Lee H-J. The toxicity of nanoparticles depends on multiple molecular and physicochemical mechanisms. Int J Mol Sci. 2017;18(12):2702.

Hwang C, Kim JM, Kim J. Influence of concentration, nanoparticle size, beam energy, and material on dose enhancement in radiation therapy. J Radiat Res. 2017:58(4):405-11.

Jayakumar S, Kunwar A, Sandur SK, Pandey BN, Chaubey RC. Differential response of DU145 and PC3 prostate cancer cells to ionizing radiation: role of reactive oxygen species, GSH and Nrf2 in radiosensitivity. Biochim Biophys Acta. 2014;1840(1):485-95.

Jiang YW, Gao G, Jia HR, Zhang X, Zhao J, Ma N, et al. copper oxide nanoparticles induce enhanced radiosensitizing effect via destructive autophagy. ACS Biomater Sci Eng. 2019;5(3):1569-79.

Khoei S, Mahdavi SR, Fakhimikabir H, Shakeri-Zadeh A, Hashemian A. The role of iron oxide nanoparticles in the radiosensitization of human prostate carcinoma cell line DU145 at megavoltage radiation energies. Int J Radiat Biol. 2014;90(5):351-6.

Konefal A, Bakoniak M, Orlef A, Maniakowski Z, Szewczuk M. Energy spectrum in water for the 6 MV X-ray therapeutic beam generated by Clinac-2300 linac. Radiat Meas. 2015;72:12-22.

Kuncic Z, Lacombe S. Nanoparticle radio-enhancement: Principles, progress and application to cancer treatment. Phys Med Biol. 2018;63(2):02TR01. 
Le Caër S. Water radiolysis: influence of oxide surfaces on $\mathrm{H}_{2}$ production under ionizing radiation. Water Mol Divers Preserv Int. 2011;3(4):235-53.

Liu R. Adsorption and dissociation of H2O on Au(111) surface: a DFT study. Comput Theor Chem. 2013;1019(1):141-5.

Liu P, Jin H, Guo Z, Ma J, Zhao J, Li D, et al. Silver nanoparticles outperform gold nanoparticles in radiosensitizing U25 cells in vitro and in an intracranial mouse model of glioma. Int J Nanomed. 2016;11:5003-14.

Liu Y, Zhang P, Li F, Jin X, Li J, Chen W, et al. Metal-based NanoEnhancers for future radiotherapy: radiosensitizing and synergistic effects on tumor cells. Theranostics. 2018;8(7):1824-49.

Lousada CM, Johansson AJ, BrinckT, Jonsson M. Reactivity of metal oxide clusters with hydrogen peroxide and water-a DFT study evaluating the performance of different exchange-correlation functionals. Phys Chem Chem Phys. 2013;15(15):5539-52.

Luchette M, Korideck H, Makrigiorgos M, Tillement O, Berbeco R. Radiation dose enhancement of gadolinium-based AGulX nanoparticles on HeLa cells. Nanomed Nanotechnol Biol Med. 2014;10(8):1751-5.

Lux F, Tran VL, Thomas E, Dufort S, Rossetti F, Martini M, et al. AGuIX ${ }^{\circledR}$ from bench to bedside-Transfer of an ultrasmall theranostic gadolinium-based nanoparticle to clinical medicine. Br J Radiol. 2018. https://doi.org/10.1259/bjr.20180 365.

Manke A, Wang L, Rojanasakul Y. Mechanisms of nanoparticle-induced oxidative stress and toxicity. Biomed Res Int. 2013;2013:e942916.

Marill J, Anesary N, Zhang P, Vivet S, Borghi E, Levy L, et al. Hafnium oxide nanoparticles: toward an in vitro predictive biological effect? Radiat Oncol. 2014;9(1):150.

McMahon SJ, Hyland WB, Muir MF, Coulter JA, Jain S, Butterworth KT, et al. Nanodosimetric effects of gold nanoparticles in megavoltage radiation therapy. Radiother Oncol. 2011;100(3):412-6.

McMahon SJ, Paganetti H, Prise KM. Optimising element choice for nanoparticle radiosensitisers. Nanoscale. 2016;8(1):581-9.

Morrison R, Rybak-Smith M, Thompson J, Thiebaut B, Hill M, Townley H. Efficacy of radiosensitizing doped titania nanoparticles under hypoxia and preparation of an embolic microparticle. Int I Nanomed. 2017;12:3851-63.

Muhammad MA, Rashid RA, Lazim RM, Dollah N, Razak KA, Rahman WN. Evaluation of radiosensitization effects by platinum nanodendrites for 6 MV photon beam radiotherapy. Radiat Phys Chem. 2018;150:40-5.

Nakayama M, Sasaki R, Ogino C, Tanaka T, Morita K, Umetsu M, et al. Titanium peroxide nanoparticles enhanced cytotoxic effects of $\mathrm{X}$-ray irradiation against pancreatic cancer model through reactive oxygen species generation in vitro and in vivo. Radiat Oncol. 2016;11(1):91.

Petrik NG, Alexandrov AB, Vall Al. Interfacial energy transfer during gamma radiolysis of water on the surface of $\mathrm{ZrO}_{2}$ and some other oxides. J Phys Chem B. 2001;105(25):5935-44.

Puangpetch T, Chavadej S, Sreethawong T. Hydrogen production over Au-loaded mesoporous-assembled $\mathrm{SrTiO}_{3}$ nanocrystal photocatalyst: effects of molecular structure and chemical properties of hole scavengers. Energy Convers Manag. 2011;52(5):2256-61.

Rahman WN, Corde S, Yagi N, Abdul Aziz SA, Annabell N, Geso M. Optimal energy for cell radiosensitivity enhancement by gold nanoparticles using synchrotron-based monoenergetic photon beams. Int J Nanomed. 2014;9:2459-67.

Retif P, Pinel S, Toussaint M, Frochot C, Chouikrat R, Bastogne T, et al. Nanoparticles for radiation therapy enhancement: the key parameters. Theranostics. 2015;5(9):1030-44.

Richmond R, Halliwell B, Chauhan J, Darbre A. Superoxide-dependent formation of hydroxyl radicals: detection of hydroxyl radicals by the hydroxylation of aromatic compounds. Anal Biochem. 1981;118(2):328-35.

Rim KT, Koo KH, Park JS. Toxicological evaluations of rare earths and their health impacts to workers: a literature review. Saf Health Work. 2013;4(1):12-26.

Rodnyi PA. Physical processes in inorganic scintillators. CRC Press; 1997. ISBN:9780849337888_CAT\# 3788.

Roeske JC, Nunez L, Hoggarth M, Labay E, Weichselbaum RR. Characterization of the theoretical radiation dose enhancement from nanoparticles. Technol Cancer Res Treat. 2007;6(5):395-401.

Roth $\mathrm{O}$, Hiroki A, LaVerne JA. Effect of $\mathrm{Al}_{2} \mathrm{O}_{3}$ nanoparticles on radiolytic $\mathrm{H}_{2} \mathrm{O}_{2}$ production in water. J Phys Chem C. 2011;115(16):8144-9.

Saenko Y, Cieslar-Pobuda A, Skonieczna M, Rzeszowska-Wolny J. Changes of Reactive oxygen and nitrogen species and mitochondrial functioning in human K562 and HL60 cells exposed to ionizing radiation. Radiat Res. 2013;180(4):360-6.

Sahu SP, Cates EL. X-ray radiocatalytic activity and mechanisms of bismuth complex oxides. J Phys Chem C. 2017;121(19):10538-45.

Saito I, Matsuura T, Inoue K. Formation of superoxide ion via one-electron transfer from electron donors to singlet oxygen. J Am Chem Soc. 1983;105(10):3200-6.

Schuemann J, McNamara AL, Warmenhoven JW, Henthorn NT, Kirkby KJ, Merchant MJ, et al. A new standard DNA damage (SDD) data format. Radiat Res. 2019;191(1):76-92.

Sicard-Roselli C, Brun E, Gilles M, Baldacchino G, Kelsey C, McQuaid H, et al. A new mechanism for hydroxyl radical production in irradiated nanoparticle solutions. Small. 2014;10(16):3338-46.

Sukhanova A, Bozrova S, Sokolov P, Berestovoy M, Karaulov A, Nabiev I. Dependence of nanoparticle toxicity on their physical and chemical properties. Nanoscale Res Lett. 2018;13(1):44.

Taggart LE, McMahon SJ, Butterworth KT, Currell FJ, Schettino G, Prise KM. Protein disulphide isomerase as a target for nanoparticle-mediated sensitisation of cancer cells to radiation. Nanotechnology. 2016;27(21):215101.

Tan T, Beydoun D, Amal R. Effects of organic hole scavengers on the photocatalytic reduction of selenium anions. J Photochem Photobiol A Chem. 2003;159(3):273-80.

Townley HE, Rapa E, Wakefield G, Dobson PJ, Xu M, Huang N, et al. Nanoparticle augmented radiation treatment decreases cancer cell proliferation. Nanomedicine. 2012;8(4):526-36.

Tzelepi K, Espinosa Garcia C, Williams P, Golding J. Galactose: PEGamine coated gold nanoparticles adhere to filopodia and cause extrinsic apoptosis. Nanoscale Adv. 2019;1 (2):807-16. 
Wang X, Zhang C, Du J, Dong X, Jian S, Yan L, et al. Enhanced generation of non-oxygen dependent free radicals by schottky-type heterostructures of $\mathrm{Au}-\mathrm{Bi}_{2} \mathrm{~S}_{3}$ nanoparticles via X-ray-induced catalytic reaction for radiosensitization. ACS Nano. 2019;13:5947-58.

Zhang D, Zhou T, He F, Rong Y, Lee SH, Wu S, et al. Reactive oxygen species formation and bystander effects in gradient irradiation on human breast cancer cells. Oncotarget. 2016;7(27):41622-36.

Zhao H, Kalivendi S, Zhang H, Joseph J, Nithipatikom K, Vásquez-Vivar J, et al. Superoxide reacts with hydroethidine but forms a fluorescent product that is distinctly different from ethidium: potential implications in intracellular fluores cence detection of superoxide. Free Radic Biol Med. 2003;34(11):1359-68.

Zhao N, Yang Z, Li B, Meng J, Shi Z, Li P, et al. RGD-conjugated mesoporous silica-encapsulated gold nanorods enhance the sensitization of triple-negative breast cancer to megavoltage radiation therapy. Int I Nanomed. 2016:11:5595-610.

Zobel M. Observing structural reorientations at solvent-nanoparticle interfaces by X-ray diffraction — putting water in the spotlight. Acta Crystallogr Sect A Found Adv. 2016;72(6):621-31. https://doi.org/10.1107/S2053273316013516.

Zobel M, Neder RB, Kimber SAJ. Universal solvent restructuring induced by colloidal nanoparticles. Science. 2015;347(6219):292-4.

\section{Publisher's Note}

Springer Nature remains neutral with regard to jurisdictional claims in published maps and institutional affiliations.

- fast, convenient online submission

- thorough peer review by experienced researchers in your field

- rapid publication on acceptance

- support for research data, including large and complex data types

- gold Open Access which fosters wider collaboration and increased citations

- maximum visibility for your research: over 100M website views per year

At BMC, research is always in progress.

Learn more biomedcentral.com/submissions 